\title{
Wooden floors: part of historical antiseismic building systems
}

\author{
Umberto Barbisan and Franco Laner \\ Dipartimento di Costruzione dell'Architettura, I.U.A.V., Venezia, Italy
}

\begin{abstract}
The article describes how wooden floors have been used over the centuries as a means of ensuring greater building solidity to ensure against earthquakes or other events that threaten wall stability.
\end{abstract}

Key words antiseismic building techniques Italy - wooden structures

\section{Introduction}

Research has revealed numerous proposals in the past to improve the resistance of buildings to earthquakes. Most of these have, however, remained academic exercises.

Viewed in Christian culture as a divine punishment, earthquakes have always been the source of atavic fear for builders. Indeed in many regions of Italy, propitiatory rites, processions and prayers to ward off seismic shocks were a feature of life right into the middle of this century.

It is hardly surprising therefore that specific antiseismic construction proposals were largely the work of scholars. However, it is no less true that the communities affected by earthquakes had the problem of rebuilding or repairing damaged buildings and this resulted in technological solutions being devised to improve standing buildings' antiseismic resistance or to offset subsidence or walls out of plumb. And when builders realized that wooden floors were a means of keeping the «wall box» together, many ways of ensuring a physical link between floor and vertical elements came into existence.

Old buildings in Venice have several systems for connecting walls to the wooden floors. In such a configuration the floors perform the dual function of stay and principal strut to counter slight but uneven subsidence of the foundations on which the building rests.

\section{Leonardo da Vinci}

One of the first documented records of masonry being secured to wooden floors come from Leonardo da Vinci, who wrote (Richter, 1883):

«Each beam shall be passed through the walls and be secured there with sufficient chains, since beams have often been dislodged, ruining walls and floors in an earthquake; where they were secured with chains, they have kept the walls firmly together and the walls in turn have secured the floors».

This summary statement reveals Leonardo's extraordinary intuition of a building's behaviour during an earthquake. Similarly, Leon Battista Alberti (1485) claimed that buildings with wooden floors were more earthquake resistant than those with arches and vaults.

It was common practice to secure the floors 
of a building to its walls well before the days of Leonardo, however.

Placing a wooden rafter into a wall to act as a connecting stay and so join the masonry to the wooden floor is an architectural feature of many rural buildings in Northern Italy, even in traditionally non-seismic areas. The oldest constructions in some of the valleys of the Italian South Tyrol display unconscious antiseismic building features: a stone foundation or base with scarp-like walls; wooden stays reinforcing the floors; upper storeys in wood, built either in the Blockbau or Fachwerk manner; nonthrust, light-weight wooden roof covering and highly symmetrical ground-plan. Such stone and wood buildings are perfect antiseismic constructions in an area which although not prone to earthquakes suffers micro-landslides, heavy snowfalls and strong seasonal winds. The result was the development of construction techniques offsetting subsidence and horizontal natural forces: wooden floors to provide horizontal connection between the masonry by means of rafters placed in direct contact with the walls - thus enabling the direct transmission of loading forces - along with the use of metal brackets and wooden dowels.

\section{Sguario and eighteenth century treatises}

Sguario published the first treatise on «seismic architecture», Specimen physico-geometricum de terraemotu ad architecturae utilitatem concinnatum, in Venice in 1756 . His was one of the first descriptions of the dynamics of standing buildings during seismic activity. For Sguario, however, floors were completely rigid septa or partitions (fig. 1).
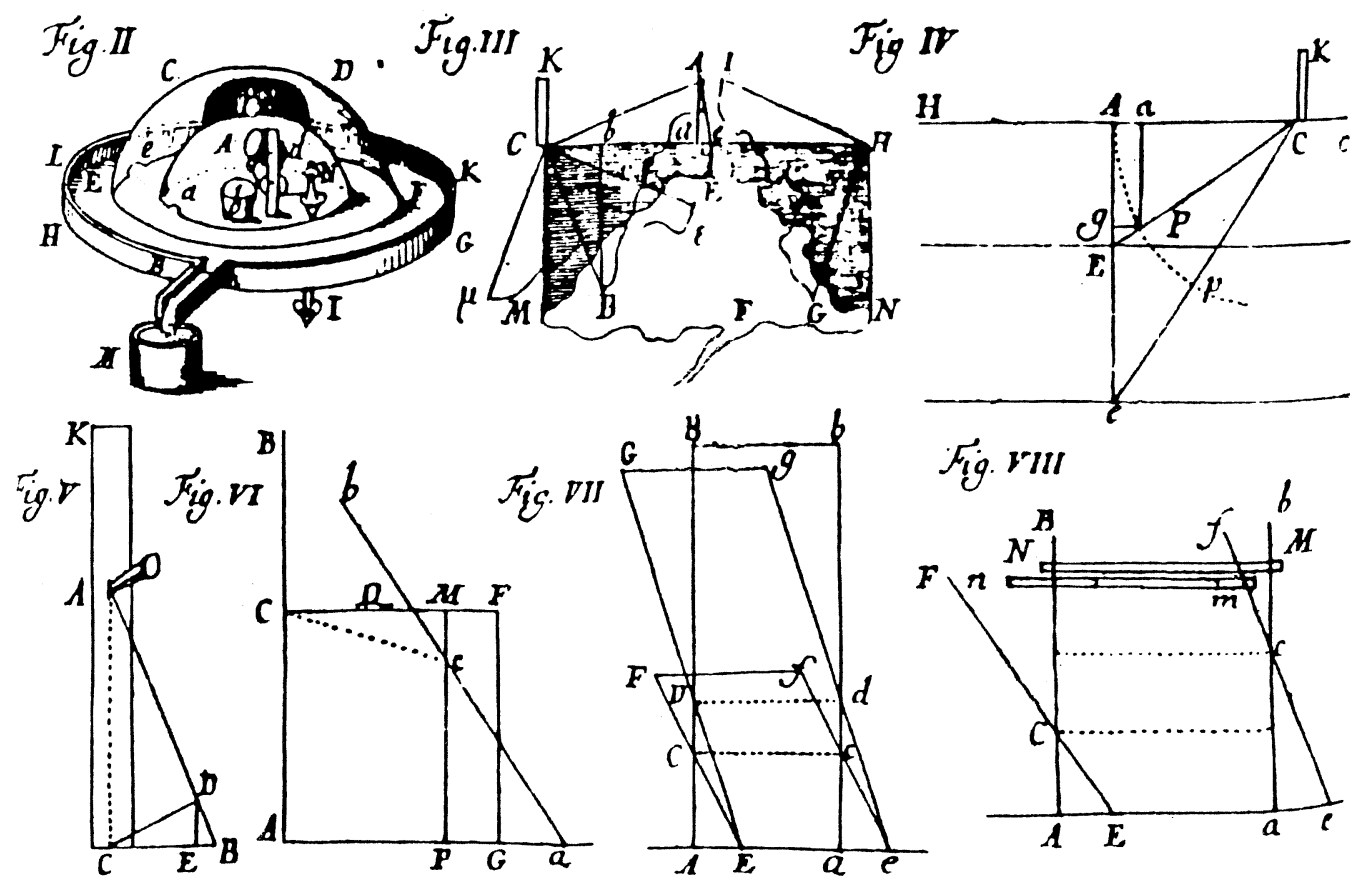

Fig. 1. Sguario Specimen physico-geometricum de terraemotu ad architecturae, Venice, 1756. Starting from the assumption that both walls and floors were completely rigid, Sguario suggests that an increase in top loading would raise the geometrical barycentre and hence reduce movement at the top of the building. 
In 1781, Milizia proposed the rule of using wooden rafters as stays for the whole building. In a specific chapter entitled Delle Case per $i$ tremuoti (On houses for earthquakes), Milizia recalls that «in order to sustain the walls, the ancients placed long wooden beams at regular intervals from one wall to another which extended over the whole thickness of the wall to serve as a chain».

The antiseismic regulations laid down in Calabria in Southern Italy in the eighteenth century following the disastrous earthquake of 1783 were the work of the military engineer, G.B. Mori who was assisted by the seismologist, Giovanni Vivenzio. They recommended this same wooden and masonry structure (Di Pasquale, 1986):

«On this basement or plinth the houses shall rest. The frame of the houses shall comprise large beams of chestnut or oak, depending on locally available wood. These shall be placed at the corners and at reasonable intervals and shall be bound to the other transverse beams placed directly on them; the same applies to the beams of the floors and the roofs. The loggias of churches, as described previously for vaulted ceilings, shall be made of beams that act as chains with bundles of iron rods nailed firmly at the top and leaving a sort of ring through which to pass an iron bar. Furthermore the beams shall be secured to the others as described for the strengthening of the roof, so connecting the whole construction. Beneath the loggias, when the supporting walls require it or in the event of unfortunate deformity, iron chains shall be placed, at the discretion of the construction engineer, so as to encompass the full width of the room».

Interesting reference is made here to the «loggias» or floors of churches serving as «chains», showing an understanding of the precarious nature of religious buildings on account of their excessively slender walls in comparison to their essentially empty interior.

\section{The nineteenth century}

The nineteenth century saw technical construction manuals based on scientific construction principles. Many contain descriptions of the mechanisms leading to the collapse of buildings under the forces of an earthquake. This led a seismologist (Pilla, 1846) to declare somewhat naively, albeit correctly, that «a well built house will better withstand the shaking of the earth just as well reinforced ship will better resist the fury of a storm than a fragile piece of wood».

One of the most widely circulated technical manuals, Le Istituzioni di Architettura Statica e Idraulica by Nicola Cavalieri di San Bertolo from Mantua, published in 1831, sets down a series of rules of good practice for antiseismic building. In fact they are a compendium of centuries-old practices reinterpreted in the light of the new science of construction. The following passage comes from the second part of the first volume:

«The violence of earthquakes and hurricanes knows no bounds. One can only advise that in those areas where such violent phenomena occur frequently that care be taken not to build too tall buildings and that vaulted ceilings be never used. The first recommendation requires no explanation; as to the second, this derives from the observation that where vertical walls are divided by a vault, when the former are shaken by earthquakes or storms, almost inevitably the latter crack and split on account of their rigidity. If, however, the floors are in wood, these, on account of the elasticity of this material, are capable of accommodating to a considerable degree the movements of the walls which hence are less in danger of upheaval and collapse».

San Bertolo is original in referring to the «elasticity» of the wooden floor, introducing the idea of dynamic energy absorption in contrast to the concept of opposing the energy released by an earthquake or the wind with a solid mass.

Favaro (1883), a well-known scholar from Padua published widely on seismic prevention. In one of his works he affirms the following:

«Experience has shown that a solid wooden frame, bound together securely, against which the masonry is then applied using suitable material, will provide adequate safety in all cases. The timber generally employed is roughly squared chestnut: this is used to construct the framework of the building, in the manner of a skeleton of the building under construction. At the level of the first floor is placed a frame- 
work of horizontal beams, almost the same cross sectional size as the upright posts; these rest, by cutting into no more than half their thickness, upon the vertical stanchions which should be left practically unscathed so as not to weaken them; on to this horizontal frame are placed the beams supporting the floor, securing them with sturdy nails. In the case of a house with several storeys, the floor beams are laid at each floor in the same direction as the beams of the previous floor. Across the rooms, two bracing floor joists are laid. All elements of this wooden frame are then secured together with large, sturdy nails driven well in and riveted. Each wall is then secured by means of iron chains as previously mentioned and the beams of the floor are connected by means of a flat iron bar at the top and in the middle. On occasion, the beams are secured at the top by the same chains used to link the walls: here too founda-
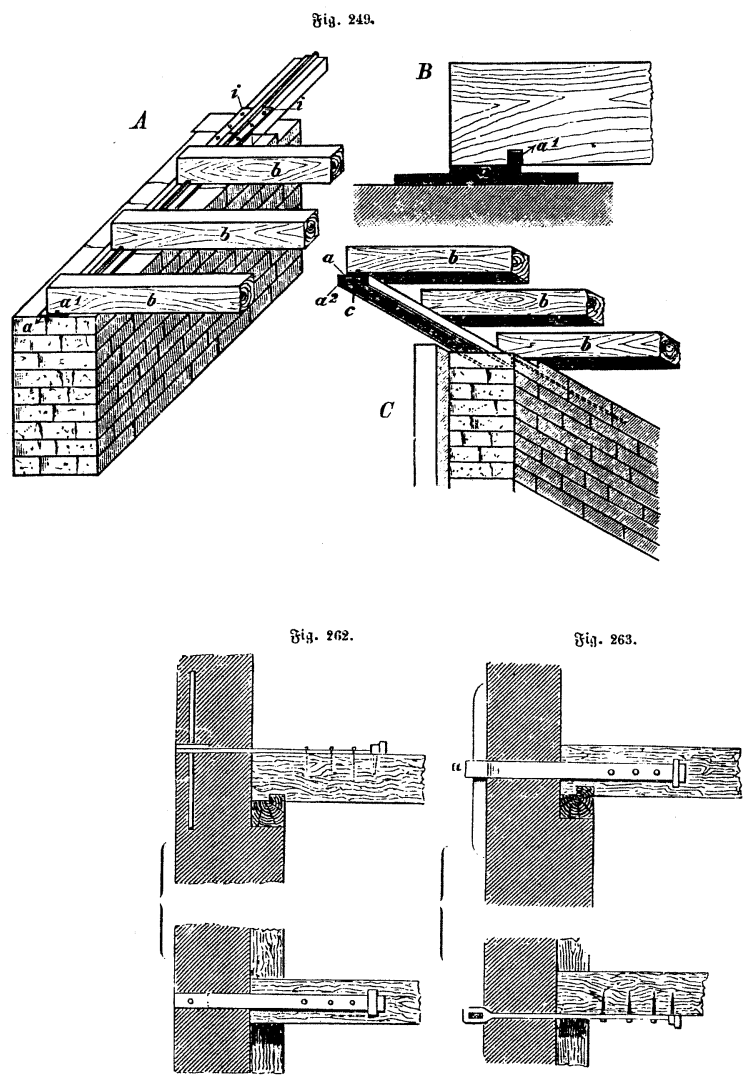

tion or rag bolts are used. A structure thus secured is highly unlikely to suffer damage to a wall or floor».

Favaro's indications reflect the norms in force in the mid nineteenth century. A. Secchi, a Jesuit priest, and L. Poletti (Norcia 1859) in their publication Progetto di regolamento da operarsi nella città di Norcia tanto nella costruzione di nuovi fabbricati quanto nel riattamento degli antichi, a treatise on the building of new constructions and adapting standing buildings, refers interestingly to the need for «the wooden beams of floors and ceilings to be laid across the whole thickness of the walls and be bound together by iron staples».
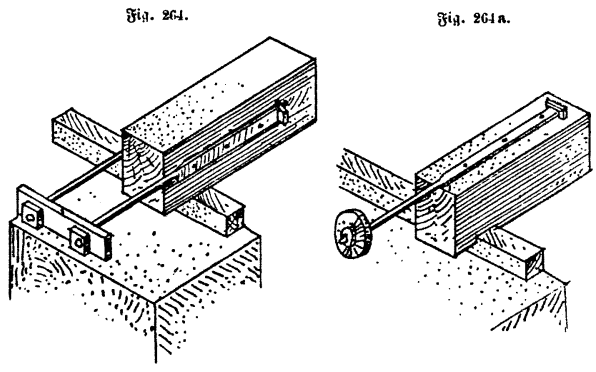

F(ad)ichicuen mit Sod)rautbenenbigutngen antbringen unto ein wagred)t liegentes ftartes Flacheifent vorf(h)rabent, Fig. 264.

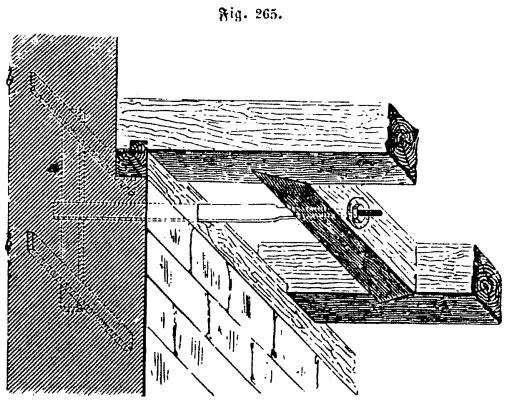

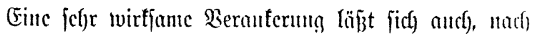

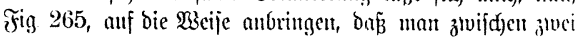

Fig. 2. Systems for anchoring wooden floors to outer walls, described by Warth, Die Konstruktionen in Holz, Lipsig, 1900. 

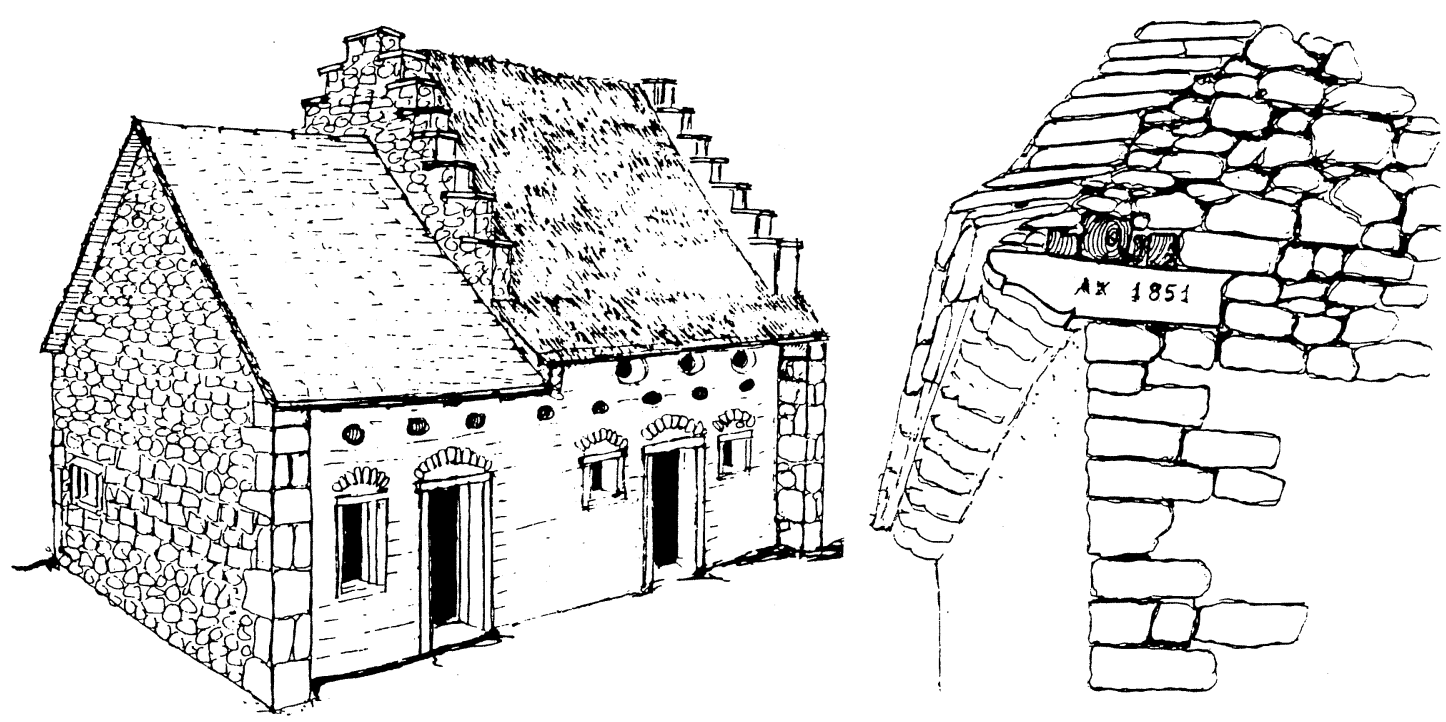

Fig. 3. Rural building in Alpago (Belluno, North-east Italy). Thatch was gradual replaced by stone slabs in the sixteenth century, which called for robust wooden structures to bear the considerable additional weight.

Even technical manuals not directly concerned with antiseismic measures contained detailed accounts of how floors should be connected to the vertical masonry. These descriptions were then taken up by specialist manuals published after seismic events such as the disastrous Messina quake.

Breymann's Baukonstruktionslehere (1853), a famous treatise that enjoyed several editions up to the early twentieth century, contains interesting construction details, revealing that the author was aware that horizontal floors contributed to the stability of the walls (fig. 2).

As a rule, however, the recommendations found in technical handbooks at the end of the nineteenth century are mainly based on traditional building techniques consolidated over the centuries.

In the seismic area of Alpago, in the Province of Belluno in North-east Italy, for example, buildings were traditional rectangular and compact, of limited height with no jutting elements, the side walls had graded pediments and the roof sloped steeply and was covered with heavy stone slabs to withstand the strong winds in this wide valley (fig. 3).
After the earthquake of June 29, 1873 in Belluno and its province, two scholars of geology and seismology, Pirona and Taramelli, were appointed by the Reale «Istituto Veneto di Lettere, Scienze ed Arti» to report on the damage caused. Taramelli, the only one who actually conducted any field surveys of the disaster area, attributed the «small number of casualties» in the Alpago valley to the particular construction of the roofs of the houses and the fact that the floors were systematically secured to the walls. Pirona and Tarmelli explain:

«In this area, roof tiles are unlikely to withstand the strong winds, especially in the winter; as a result it is common practice to cover roofs with blue or pink Scaglia stone slabs, 40 to $50 \mathrm{~mm}$ thick, which are laid in overlapping fashion so as to have a minumum thickness of no less than $25 \mathrm{cms}$. The weight loading on the walls, which often extend as high as 3 storeys, can well be imagined. This appears to have been well understood by even the poor people of Alpago since their custom is to employ numerous timber stanchions of the stoutest quality, joined together with long iron pins, to bear the enormous weight. This construction system has been responsible for two miraculous events: the enormous damage to the buildings and the relatively small number 
of casualties. The walls, violently shaken by the earthquake and subjected to the enormous thrusting load of the roof, collapsed only when the stone slabs slipped from the steeply sloping roof; however, the beams connected together to form the timber scaffold very often resisted as did the frame of the roofs, made up of numerous sturdy rafters, or if they fell, formed a bridge protecting the people in their beds below from the rubble».

In this case the construction requirement of heavy roof covering to resist strong winds was deleterious for earthquake safety since it increased the mass bearing down on the top of the building. At the same time, however, the technique demanded solid masonry and a sturdy, well connected wooden framework with wooden rafters and beams passing through the full thickness of the walls.

There is a strong conceptual link between wind and seismic stresses since the solutions devised to counter wind indirectly may provide protection against seismic activity and viceversa. In this particular region, however, earthquakes have occurred sufficiently infrequently for the lessons learned to be forgotten, while high winds are seasonal and the horizontal stress they created were very much clearer in the minds of builders although not completely understood.

\section{The great Messina earthquake}

The Messina earthquake of 1908 gave considerable impetus to antiseismic building research. This resulted in the adoption of a more modern approach to earthquakes which were no longer seen as a punishment but rather as the release of violent natural forces that could be measured in terms of dynamic horizontal loads and, for ease of comprehension, represented in static diagrammatic form.

Although the proposals and interpretations reveal a good understanding of earthquake phenomena and consistent application of new scientific building criteria, the numerous patents covering antiseismic construction techniques that appeared after the Messina quake were still based on conventional building customs (fig. 4).
The patents cover of whole series of proposals ranging from the extravagant to the highly practical. Many projects return to the wooden framework locked into the masonry, with the floor playing a vital role as the element which, in the words of a patent deposited on 24.6.1909 with the Patent Bureau in Rome by one Pasquale Frezza, «yields and accommodates any movement or seismic wave».

Masciari-Genoese's well-known text book of 1915 (pp. 662-680) makes reference to several of these patents registered after Messina (fig. 5). In a special chapter on floors he writes:

«A well built floor that distributes the weight to all sides like a vault or calotte and holds firmly together all the perimeter walls so as to render them inflexible to lateral forces and able to withstand deforming loading stresses and so ensure that walls and floor form a single, almost monolithic, broad-based unit, even if it exerts an extra load on these same walls, is always the best horizontal element with which to connect and secure a building, just like a crate of slender flexible planks is rendered solid and sound by the bottom frame which is securely nailed together around the perimeter. In the same way a building's floor allows the height of the the walls to be doubled, tripled or quadripled, in other words to be 30,40 or even more times their thickness and

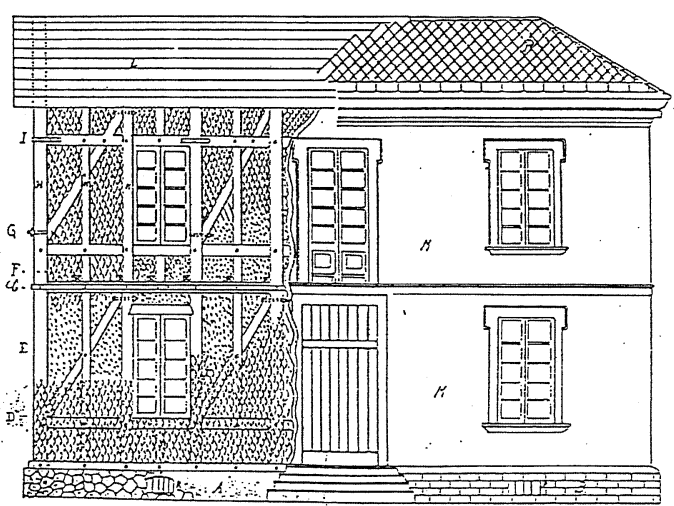

Fig. 4. Elevation of an «antiseismic house» described in patent submitted by Luigi Lanza on 1.3.1909 to the Central Patents Bureau in Rome. Building with wooden frame, stretched plate and plastering. 

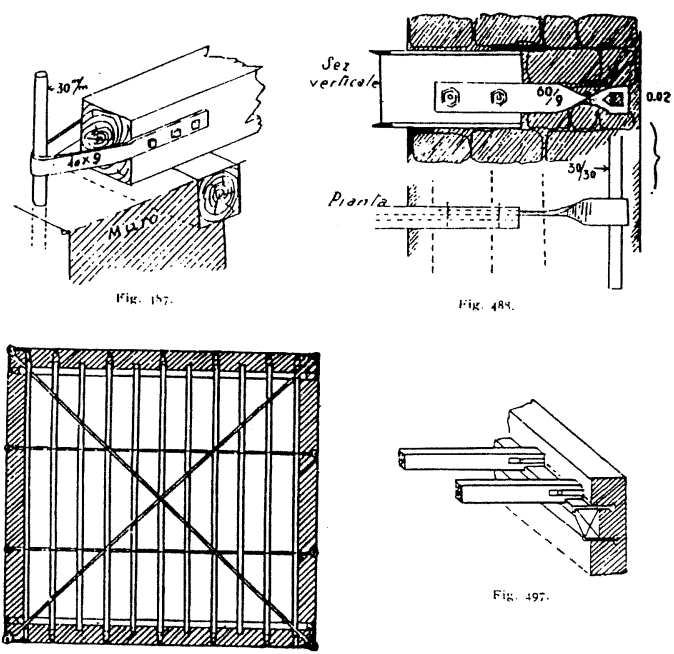

Fir. 4 BY.

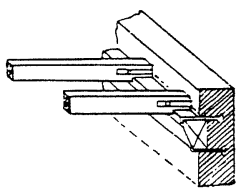

Fi... 49 ;

Fig. 491.

Fig. 5. Solutions to anchor floor and walls; diagonal and horizontal bracing of floor frame proposed by Masciari-Genoese in Trattato di costruzioni antisismiche, Milan, 1915.

even tapered with successive wall steps, whereas if taken singly, the walls could not exceed a height of more than 10 or 12 times their thickness. Intermittent shocks subject the floor to vertical flexion stresses while undulatory shocks, on account of their asynchronous nature, subject the floor to alternating horizontal traction and compression... Statically floors do not produce thrusting forces against the walls like vaults and hence are to be preferred in earthquake prone areas: during undulatory shock movement, however, their mass does determine some thrusting stress which is proportional to their weight and the additional loads their invariably bear. On the other hand, as has been mentioned, floors are an effective means of linking and securing opposite walls, when the beams are equipped with staples and bolts at their extremities and tranversely secured to the outer walls keeping these rigid despite their great height compared to their width... Inadequate bearing and the lack of staples and bolts will cause the floor to collapse and in so doing create thrusting forces that will fracture the walls».

Masciari continues making some original observations on the behaviour of wooden floors to fire, a frequent occurence following an earthquake. He also notes that «I-shaped iron» floors are not without danger since «if they catch fire, they dilate, bend, become warped and contorted».

$\mathrm{He}$ is very clear in his recommendation of the box-shaped building, proposing that the beams of one floor be laid at right angles to the subsequent floor and discourages the use of floors whose main rafters are in segments, which would cause load concentration. He further suggests inserting a horizontal cross bracing at the intrados of the floor to prevent warping.

Masciari is concerned with dynamic loads, affirming that «regular intermittent shocks can multiple up to 13 fold the effect of a mobile topload, which signifies largely exceeding the safety limit of the safety coefficient». Despite the fact that Masciari obviously understood how seismic and wind stresses could be transformed into lateral static loading forces, his «formulae» for dimensioning floors do not, however, include any specific antiseismic measures. Rather he relies on the improved construction techniques he advocates to provide seismic resistance.

The new, more scientific approach was the result of joint concern on the part of legislators, universities, professional and technical experts. That some of Masciari's proposals and certain of the antiseismic constructions patented do not stand up to very close scrutiny is of less importance than the new widespread desire they denote to provide antiseismic construction techniques with a solid scientific base.

It seems that there was wide concensus that floors function as flexible horizontal elements connecting the surrounding walls and absorbing seismic shocks, first by the fact of being coupled to the walls and secondly, by accommodating the compression-flexion and traction forces of an earthquake and the synchronous or asynchronous movement of the perimeter walls.

There was a general awareness that wooden floors are less rigid than masonry walls and so, if these were well knit together, the wooden elements would be able to absorb the seismic energy and generally make the whole building more resistant. Most examples of collapsed 
buildings that had wooden floors and masonry walls pointed to the need to secure effective coupling between walls and floors.

In fact the floors constructed according to traditional building techniques are not infinitely rigid. As a result, their energy absorbing capacity depends on the plastic yield resistance of the wood and thus, on the effectiveness of the link with the perimeter walls.

The empirical solution to ensure that floor and ceiling rafters fitted tightly into the walls and were further secured with metal brackets, wooden pegs or beams resting on the whole width of the walls, proved a valid means of im-

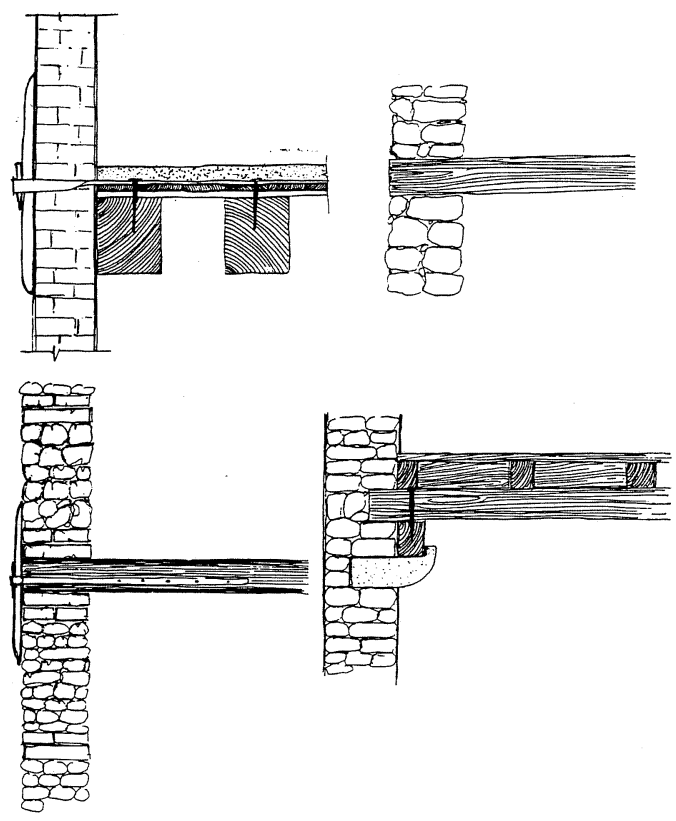

Fig. 6. Examples of floor and wall couplings taken from historic buildings in the Veneto region. Top left, coupling set at right angles to the direction of the beams (eighteenth century villa in the Veneto region); top right, beam inserted right into the wall and flush with the outer side (rural building at Altivole (Treviso); bottom left, the use of a «bolzone» or long bolt placed on the side of the beams; bottom right, hook-shaped stone support, from the Abbey at Follina (Treviso) and also seen in the Palazzo del Bo' in Padua. proving building resistance to earthquakes, even if most of these solutions were devised for reasons other than antiseismic safeguard (fig. 6). For example, rural buildings in the Veneto region are frequently found with floor beams that jut out beyond the wall; the aim was rather to counter the heavy loads placed on the wooden floor. But in the event of an earthquake, this layout helped considerably to dampen transmitted energy (fig. 7).

As Gavarini and Longhi point out (1991), there are four main types of construction techniques used in old buildings to improve antiseismic performance. These are:

- the addition of reinforcing elements such as buttresses, new walls, counterforts, etc.;

- repairs using the «undo-redo» method;

- positioning horizontal ties (chains);

- insertion of buttressing elements between contiguous buildings. The only defect of such techniques is that they have largely been forgotten by technical experts and masons alike. This, along with the difficulty of assessing their worth in numerical terms has meant that they have been (unjustly) considered unreliable by modern thinkers».

In the light of surveys conducted in the seismic areas of Veneto and Friuli-Venezia Giulia we can add the following to the list:

- low load roofs;

- wooden or metal reinforcement cerclage;

- metal ties or stays;

- floor beams coupled to the outer walls by various means;

- reinforced door and window frames;

- walls reinforced with wooden members;

- particular care taken in the fabrication of wall angles;

- various solutions of external counterforts and buttresses.

The above solutions, together with many others, were part of the baggage of construction skills of the past. They provided often original solutions whose scope and implementation are difficult and complex to assess today.

In conclusion, from the XII-XIV century onward the wooden floor was considered by 


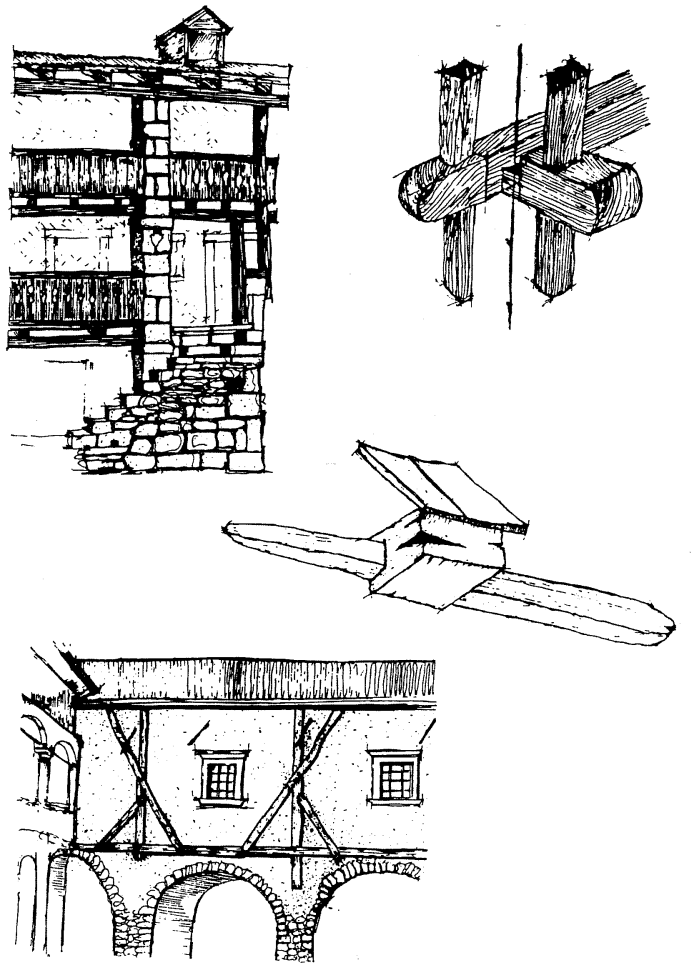

Fig. 7. The insertion of wood into the masonry in buildings in Friuli (North-east Italy) and in Southern Austria. From Barbisan, La ricerca dell'archetipo, Angeli, Milan, 1994.

the building trade as a means of creating a tightly connected box construction comprising walls and floor. Whether the resultant antiseismic effect was consciously sought or merely a chance benefit afforded by traditional building techniques is difficult to ascertain.

\section{REFERENCES}

AlBERTI, L.B. (1485): De re aedificatoria, vol. V, edited by C. BARTOLI, Della architettura libri dieci di L.B. Alberti, Milano, 1833.

Augusti, G., A. Ceccotti and A. Vignoli (1984): Strutture di legno lamellare incollato di grande luce: prove statiche e dinamiche, in atti del Il Convegno Nazionale sull'Ingegneria Sismica in Italia, Rapallo.

Av.Vv. (1982): Comportamento statico e sismico delle strutture murarie (Clup, Milano).
BARBISAN, U. (1989): Adeguamento sismico: cenni storici in Av.Vv., Gemona scoprire il passato pensando al futuro, Gemona (Ud).

BARBISAN, U. (1991): Il legno nelle costruzioni in zona sismica, Recuperare, 8.

BARBISAN, U. (1991): Considerazioni sugli interventi in zona sismica, Galileo, 17, Padova.

BARBISAN, U. (1991): Il legno nelle costruzioni in zona sismica, Recuperare, october.

BARBISAN, U. and F. LANER (1983): Terremoto ed architettura (Cluva, Venezia).

Barbisan, U., G. Gambirasio, G. Brusati and F. LANER (1984): Evoluzione storica dei sistemi di protezione sismica, in L'industria Italiana delle Costruzioni, 155.

BARBISAN, U. and F. LANER (1995): I solai in legno (Angeli, Milano).

BARUCCI, C. (1990): La casa antisismica: prototipi $e$ brevetti (Gangemi, Roma).

BREYMANN, G.A. (1853): Baukonstruktionslehere, Stoccarda, published in Italy with the title Trattato generale di costruzioni civili, Milano, 1885.

CAVAlieri di SAN Bertolo, N. (1853): Istituzioni di architettura statica e idraulica, Mantova.

CeccotTI, A. (1983): Rafforzamento antisismico di antiche strutture di legno: problemi progettuali ed operativi, in Atti Convegno Aniani, Firenze.

CECCOTTI, A. (1989): La verifica strutturale di costruzioni in legno in zona sismica, Progetto Legno, 6.

CENCI, G. (1980): Progetto guida casa antisismica '80, Il Legno, 14.

Cenci, G. (1980): Strutture in legno, Milano.

Como, M. and G. LANNI (1979): Elementi di costruzioni antisismiche, Roma.

Di PASQuale, S. (1986): Architettura e terremoti, in AA. Vv., Architettura e terremoti. Il caso di Parma, Parma, $38-40$.

Doglioni, F. (Editor) (1980): Prontuario del restauro, in Progetti e Ricerche della Città di Pesaro, No. 7, suppl. Pesaro, No. 10.

DonGHI, D. (1906): Manuale dell'architetto, Torino.

Dowrick, D.J. (1981): Progettazione antisismica (tr. it. Hoepli, Milano).

EMY, A.R. (1856): Trattato dell'arte del carpentiere (tr. it. Venezia).

FAVARO, A. (1883): Norme di costruzione per aumentare la resistenza sismica degli edifici contro il terremoto, in Atti dell'Istituto Veneto di Lettere, Scienze ed Arti, Venezia.

Gavarini, C. and G. LongHI (1991): Protezione sismica dei monumenti, in Ingegneria antisismica, edited by G. Gavarini, A. Giuffrè and G. Longhi (Esa, Milano), p. 159.

Gavarini, C., A. GiUfFrè and G. LONGHI (1991): Ingegneria antisismica (Esa, Milano).

GIUfFrè, A. (Editor) (1993): Sicurezza e conservazione dei centri storici. Il caso Ortigia (Laterza, Roma-Bari).

LANER, F. (1991): Il recupero dei solai, Recuperare, 2.

LANER, F. (1991): L'essenza per costruire con il legno, $R e$ cuperare, 4.

LANER, F. (1992): Eteroclisia da riciclaggio, Recuperare, 3 . 
LANER, F. and U. BARBISAN (1985): Le regole architettoniche di E. Sguario nel settecento, in Architetti Venezia, 1.

LANER, F. and U. BARBISAN (1985): Le origini della progettazione antisismica, in Il Nuovo Cantiere, 11.

LANER, F. and U. BARBISAN (1985): Notes for a protocol for the antiseismic adaptation of standing building, in Atti International Conference on Seismic Prone Areas, Unesco, Skopje (Yu).

LANER, F. and U. BARBISAN (1985): Il legno lamellare nel riuso edilizio, in Atti del Convegno Riabitat Tecniche $e$ Tecnologie per il Recupero (Ed. Sagep, Genova).

LANER, F. and U. BARBISAN (1986): Alcune note sull'impiego del legno quale contributo al recupero della concezione strutturale dell'edificato veneziano, in Restauro e Città, 3/4 (Marsilio, Venezia).

LANER, F. and U. BARBISAN (1986): I secoli bui del terremoto (Angeli, Milano).

LANER, F. and U. BARBISAN (1987): Antiseismic adaptation of standing building in Italy, in Atti International Congress on City and Architecture in Seismic Area, Mendoza, Argentina.
MASCIARI-Genoese, F. (1915): Trattato di costruzioni antisismiche, Milano.

MedeARIs, K. (1966): Static and dynamic properties of shear structures, in Atti del Convegno Rileu, Città del Messico.

Milizia, F. (1781): Principi di architettura civile, Final, parte II, table III, chap. IX.

Munafò, P. (1991): Recupero dei solai in legno (Ed. Flaccovio, Palermo).

PILla, L. (1846): Istoria del tremuoto che devastato i paesi della costa di Toscana il dì di 14 agosto 1846, Pisa.

PoliJkov, S.V. (1987): Costruzioni antisismiche degli edifici (tr. it. Mir, Mosca).

RICHTER, J.P. (1883): The literary works of Leonardo da Vinci, Londra, vol. II, p. 99.

Rondelet, J.B. (1831): Trattato teorico pratico dell'arte di edificare (tr. it. Mantova).

SANSON, A. (1992): L'uscita dai secoli bui: storia e valutazione dei brevetti per costruzioni antisismiche nel dopoterremoto di Messina del 1908, Thesis, F. LANER, U. BARBISAN, IVAV, Venezia.

Wakabayaschi, M. (1989): Progettazione di strutture antisismiche (McGraw-Hill, Milano). 